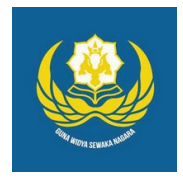

Jurnal Analogi Hukum

Journal Homepage: https://ejournal.warmadewa.ac.id/index.php/analogihukum

\title{
Status Kewarganegaraan Anak Hasil Perkawinan Campuran yang Lahir Pasca berlakunya Undang-Undang Nomor 12 Tahun 2006 tentang Kewarganegaraan Republik Indonesia
}

\author{
I Putu Gede Bayu Sudarmawan*, I Gusti Bagus Suryawan dan Luh Putu Suryani
}

Fakultas Hukum, Universitas Warmadewa, Denpasar, Bali-Indonesia

*bayu.sudarmawan@gmail.com

How To Cite:

Sudarmawan, I. P. G. B., Suryawan, I. G. B., \&., Suryani, L. P. (2020). Status Kewarganegaraan Anak Hasil Perkawinan Campuran yang Lahir Pasca berlakunya Undang-Undang Nomor 12 Tahun 2006 tentang Kewarganegaraan Republik Indonesia . Analogi Hukum. 2(1). 88 -92. Doi: http://dx.doi.org/10.22225/.2.1.1629.88-92

\begin{abstract}
In many societies, marriage customs, who married her partner of different nationality for example a man citizen of Indonesia who married women foreign nationals or otherwise. It is caused due to the influence of globalization today. Of course, the marriage will having problems in the determination of citizenship status if they have children, especially if they settled in Indonesia. This research intended to find answers about the determination of the status of citizenship of children born of mixed marriages and the legal protection of children of mixed marriages that result. This research uses research methods through a conceptual approach to normative. The author uses primary law binding and also secondary legal material as a reference. The results of this research is the child of a mixed marriage deserve the status of dual citizenship is limited and is also entitled to preventive legal protection to guarantee the certainty of the law as a citizen of Indonesia.
\end{abstract}

Keywords: children, mixed marriage, citizenship status.

\begin{abstract}
Abstrak-Dalam melangsungkan perkawinan, banyak masyarakat yang menikah dengan pasangannya yang berbeda kewarganegaraan misalnya seorang pria warga negara Indonesia yang menikah dengan wanita warga negara asing ataupun sebaliknya. Itu disebabkan karena pengaruh globalisasi saat ini. Tentu saja perkawinan tersebut akan menimbulkan masalah dalam penentuan status kewarganegaraan apabila pasangan tersebut memiliki anak, terutama apabila pasangan tersebut menetap di Indonesia. Penelitian ini dimaksudkan untuk menemukan jawaban tentang penentuan status kewarganegaraan anak yang lahir dari perkawinan campuran tersebut dan perlindungan hukum terhadap anak hasil perkawinan campuran terserbut. Penelitian ini menggunakan metode penelitian normatif melalui pendekatan konseptual. Penulis menggunakan bahan hukum primer yang bersifat mengikat dan juga bahan hukum sekunder sebagai referensi. Hasil penelitian ini adalah anak hasil perkawinan campuran berhak mendapatkan status kewarganegaraan ganda terbatas dan juga berhak mendapatkan perlindungan hukum preventif untuk menjamin kepastian hukumnya sebagai warga negara Indonesia.
\end{abstract}

Kata kunci: anak, perkawinan campuran, status kewarganegaraan.

\section{Pendahuluan}

Setiap manusia tidak dapat hidup sendiri dan terpisah dari kelompoknya, karena manusia merupakan makhluk social yang harus hidup secara berdampingan serta berusaha untuk meneruskan keturunannya dengan cara melakukan atau melangsungkan perkawinan. Perkawinan sendiri merupakan suatu ikatan pertalian yang sah antara seorang pria dan wanita dengan tujuan untuk membentuk rumah tangga yang abadi berdasarkan Ketuhanan Yang
Maha Esa serta untuk memperoleh keturunan yang suputra. Perkawinan merupakan peristiwa penting bagi manusia, dimana mereka yang melangsungkan perkawinan dianggap sudah memiliki ikatan lahir dan batin satu sama lain. Menurut Sayuti Thalib, perkawinan adalah perjanjian suci untuk membentuk keluarga antara seorang laki-laki dengan seorang perempuan (Thalib, 2009).

Dewasa ini dengan semakin berkembangnya kehidupan manusia, sangat 
diperlukan hukum atau perangkat hukum untuk mengatur kehidupan manusia tersebut. Dalam hal ini khususnya untuk mengatur perkawinan. Perkawinan itu sendiri ada dua jenis yaitu perkawinan biasa dan perkawinan campuran. Perlu diketahui, di Indonesia sudah ada aturan hukum yang mengatur khusus masalah perkawinan yaitu Undang-Undang Nomor 1 Tahun 1974. Menurut undang-undang tersebut yang dimaksud perkawinan adalah ikatan lahir batin antara seorang pria dan wanita sebagai pasangan suami istri dengan tujuan untuk membentuk keluarga yang bahagia dan kekal yang berdasarkan Ketuhanan Yang Maha Esa. Sedangkan yang dimaksud perkawinan campuran adalah perkawinan antara dua orang yang di Indonesia tunduk pada hukum yang berlainan karena perbedaan kewarganegaraan yang salah satu pihak berkewarganegaraan asing dan pihak lain berkewarganegaraan Indonesia.

Perlu diketahui diera globalisasi seperti sekarang sudah banyak warga negara Indonesia yang melangsungkan perkawinan campuran, baik itu laki-laki maupun perempuan. Tentu saja ada banyak faktor penyebabnya diantaranya karena globalisasi informasi, ekonomi, dan juga karena status kehidupan social dari warga negara asing yang dianggap lebih mapan ataupun sebaliknya sehingga menyebabkan pasangan yang berbeda kewarganegaraan dan juga berbeda kultur budaya ini untuk memilih melakukan perkawinan campuran.

Tentu saja hal tersebut akan menyebabkan timbulnya konsekuensi hukum yakni mengenai masalah kewaraganegaraan baik bagi masingmasing pihak yang melakukan perkawinan campuran maupun bagi anak-anak yang lahir dari perkawinan campuran tersebut. Itu karena setiap negara mempunyai asas yang berbedabeda tentang penentuan status kewarganegaraan seseorang yang mana status kewarganegaraan tersebut akan menentukan hak dan juga kewajibannya sebagai warga negara suatu Negara (Sitorus, 2004).

Di Indonesia sendiri dalam kasus perkawinan campuran memang tidak memberikan status kewarganegaaan Indonesia secara otomatis bagi warga negara asing yang menikah dengan warga negara Indonesia. Namun apabila mereka ingin mendapatkan kewarganegaraan Indonesia, maka mereka harus mengajukan permohonan resmi kepada instansi yang berwenang sesuai peraturan yang berlaku. Demikian pula bagi wanita warga negara Indonesia dapat mempertahankan kewarganegaraan Indonesia yang dimilikinya, namun itu akan menimbulkan masalah hukum nantinya bagi anak-anak mereka baik selama perkawinan itu berlangsung maupun setelah putusnya perkawinan tersebut.

Terjadinya perubahan terhadap undangundang kewarganegaran Indonesia merupakan suatu lompatan besar tentang kejelasan hak dan kewajiban serta kepastian hukum terhadap pengaturan status kewarganegaraan bagi anakanak hasil perkawinan campuran. Yang mana dalam ketentuan undang-undang kewarganegaran yang lama, anak-anak yang lahir dari perkawinan campuran status kewarganegaraannya otomatis mengikuti ayah mereka. Hal tersebut tentu saja membatasi hubungan antara ibu dan anak tersebut. Namun menurut Hukum Perdata Internasional dalam menentukan status anak dan hubungan antara anak dengan orang tuanya perlu dilihat terlebih dulu apakah perkawinan orang tuanya sah atau tidak, jika sah maka anak memiliki hubungan hukum dengan ayahnya dan jika tidak sah maka anak memiliki hubungan hukum dengan ibunya.

Sedangkan dalam pengaturan status kewarganegaraan anak hasil perkawinan campuran perlu diketahui terlebih dahulu apakah anak itu lahir sebelum berlakunya undang-undang kewarganegaraan yang baru atau setelah undang-undang tersebut berlaku. Apabila ia lahir sebelum undang-undang tersebut berlaku dan tetap tinggal di Indonesia sampai undang-undang ini berlaku, maka anak tersebut harus didaftarkan oleh orang tuanya paling lama 4 tahun setelah berlakunya undangundang ini agar mendapat pengakuan serta perlindungan hukum sebagai warga negara Indonesia. Namun bagaimana pengaturan status kewarganegaraannya jika anak hasil perkawinan campuran ini lahir pasca berlakunya undang-undang kewarganegaraan yang baru di Indonesia?

Dari uraian latar belakang tersebut, penelitian ini dilakukan untuk menganalisis pengaturan status kewarganegaraan serta tata pendaftaran anak hasil perkawinan campuran pasca berlakunya Undang-Undang Nomor 12 tahun 2006 dan konsekuensi serta perlindungan hukum terhadap anak hasil perkawinan campuran tersebut

\section{Metode}

Metode penelitian menjabarkan perolehan informasi dan data dalam penelitian ini yang diawali dengan pencarian, pengumpulan dan analisis bahan hukum yang sifatnya ilmiah. Metode diperlukan dalam sebuah penelitian karena bertujuan untuk mempelajari gejala 
hukum yang ditimbulkan dari penelitian itu secara sistematis.

Tipe penelitian ini tergolong penelitian normatif yaitu penelitian yang difokuskan untuk mengkaji penerapan kaidah atau norma dalam hukum positif (Ibrahim, 2006). Pada penelitian ini, menggunakan bahan hukum yang diperoleh dari studi kepustakaan yaitu, Bahan Hukum Primer antara lain KHUPerdata, UndangUndang Nomor 12 Tahun 2006 tentang Kewarganegaraan Republik Indonesia, Peraturan Menteri Hukum dan HAM RI Nomor 22 Tahun 2012 tentang Tata Cara Pendaftaran Anak Berkewarganegaraan Ganda dan Permohonan Fasilitas Keimigrasian. Bahan Hukum Sekunder meliputi literatur, jurnal, artikel dan hasil-hasil penelitian.

Pengumpulan bahan hukum dilakukan dengan cara membaca dan mempelajari serta memeriksa dokumen, buku serta hasil-hasil penelitian yang kemudian dijadikan bahan sebagai analisis permasalan agar dapat menarik simpulan sebagai bentuk interpretasi atas objek secara konsisten sehingga memberikan saran sesuai permasalahan.

\section{Hasil dan Pembahasan}

\section{Pengaturan Status Kewarganegaraan Anak Hasil Perkawinan Campuran}

Hampir setengah abad pengaturan mengenai kewarganegaraan dalam hal perkawinan campuran antara warga negara asing dengan warga negara Indonesia diatur dalam Undang-Undang Nomor 62 Tahun 1958. Yang mana dalam undang-undang tersebut sangat membatasi hubungan antara ibu dengan anaknya terlebih lagi jika perkawinan tersebut putus karena perceraian sehingga banyak masyarakat serta golongan yang berpendapat bahwa undang-undang itu sudah tidak sanggup untuk mendasari serta menampung kepentingan para pihak dalam perkawinan campuran terutama dalam hal pengaturan masalah kewarganegaraan bagi anak-anak hasil perkawinan campuran tersebut.

Untuk itu akhirnya pada tahun 2006 akhirnya undang-undang tersebut diganti dengan Undang-Undang Nomor 12 Tahun 2006 yang mana dengan lahirnya undang-undang yang baru ini dapat mengurangi permasalahan yang timbul dari perkawinan campuran salah satunya yaitu dalam pengaturan status kewarganegaraan anak hasil perkawinan campuran.

Setelah berlakunya undang-undang tersebut di Indonesia maka secara otomatis Indonesia menganut system kewarganegaraan ganda. Artinya anak-anak yang lahir dari perkawinan campuran pasca berlakunya undang -undang ini dapat memiliki atau memperoleh kewarganegaraan ganda, baik kewarganegaran ibunya atau pun kewarganegaraan ayahnya sampai ia berumur 18 tahun atau paling lambat saat ia berumur 21 tahun harus sudah memiliki satu kewarganegaraan tetap. Itu artinya anak dapat memiliki kewarganegaran ganda namun sifatnya terbatas sampai umur 18 tahun.

Dengan pemberian status kewarganegaraan ganda terbatas terhadap anak-anak hasil perkawinan campuran merupakan satu hal yang positif bagi anak, terlebih lagi bahwa yang berhak mendapatkan kewarganegaraan ganda terbatas ini tidak hanya anak hasil perkawinan campuran yang sah tetapi juga berlaku bagi anak yang lahir dari perkawinan campuran luar kawin yang diakui secara sah oleh ayahnya yang berkewarganegaraan asing. Selain berhak mendapatkan kewarganegaraan ganda, dalam undang-undang ini dijelaskan bahwa anak hasil perkawinan campuran berhak mendapatkan akta kelahiran Indonesia sehingga anak berhak mendapatkan pelayanan public termasuk untuk mendapatkan Pendidikan di Indonesia. Dimana aturan itu berbanding terbalik dengan aturan undang-undang kewarganegaraan lama dimana anak yang lahir dari perkawinan campuran sangat sulit untuk mendapat pelayanan publik serta diharuskan memperpanjang syarat-syarat keimigrasian jika tinggal di Indonesia (Jehani \& Harpen, 2006).

Namun perlu diketahui sebelumnya, apabila anak hasil perkawinan campuran tersebut lahir sebelum berlakunya undangundang ini dan tetap tinggal di indoneisa sampai undang-undang ini berlaku, maka anak tersebut harus didaftarkan paling lambat 4 tahun pasca berlakunya undang-undang ini yaitu sampai 1 Agustus 2010 di Departemen Hukum dan HAM tempat tinggal anak tersebut. Namun jika anak lahir pasca berlakunya undangundang ini, maka secara otomatis ia mendapatkan status kewarganegaraan ganda terbatas dan memperoleh affidafit yaitu surat keterangan keimigrasian yang dilekatkan pada paspor asing anak berkewarganegaraan ganda agar dapat memperoleh fasilitas keimigrasian selama keluar masuk Indonesia dan affidafit ini diperlukan untuk penerbitan paspor Republik Indonesia bagi yang bersangkutan.

Dalam proses pendaftarannya sendiri, saat ini tepatnya pada tahun 2017 kementerian Hukum dan HAM RI sudah memberlakukan proses pendaftaran anak agar memiliki

Jurnal Analogi Hukum, Volume 2, Nomor 1, 2020. CC-BY-SA 4.o License 
kewarganegaran ganda dan memilih kewarganegaraannya secara online. Hal ini bertujuan untuk memudahkan para orang tua yang melakukan perkawinan campuran untuk mendaftarakan anak-anak mereka dimana saja dan kapan saja karena system online ini bekerja selama 24 jam penuh dengan melengkapi persyaratan diantaranya : 1) Akta kelahiran anak yang bersangkutan; 2) Akta perkawinan orang tua; 3) Pas Photo ukuran 4x6; 4) Kutipan SK Menteri Hukum dan HAM tentang penetapan kewarganegaraan ganda bagi anak yang lahir sebelum 1 Agustus 2006; 5) Affidavit untuk anak yang lahir setelah 1 Agustus 2006; dan 6) Surat Izin dari konsulat asing kewarganegaraan anak yang bersangkutan. Seluruh persyaratan tersebut harus berbentuk softcopy baik berupa format .jpeg maupun .pdf.

\section{Konsekuensi dan Perlindungan Hukum Anak Hasil Perkawinan Campuran}

Setelah melakukan pendaftaran tersebut, maka secara otomatis anak memiliki hak dan juga kewajiban sebagai warga negara Indonesia. Selain itu, anak juga secara otomatis menjadi subyek hukum sehingga hal tersebut menimbulkan akibat hukum yang dapat berupa pengaturan status kewarganegaraan, hak yang mungkin timbul serta dimiliki setelah anak tersebut lahir dan didaftarkan serta tentang upaya perlindungan hukum yang mungkin dilakukan untuk melindungi hak yang di miliki oleh anak tersebut.

Di Indonesia, anak yang lahir dari perkawinan campuran yang sudah berstatus kewarganegaraan ganda mempunyai hak diantaranya hak untuk melangsungkan perkawinan di wilayah Indonesia dengan memenuhi syarat-syarat yang sudah diatur dalam Undang-Undang Nomor 1 Tahun 1974 salah satunya yaitu harus berumur 19 tahun untuk laki-laki dan 16 tahun untuk perempuan. Ketika anak berkewarganegaraan ganda tersebut berdomisili di Indonesia dan hendak melangsungkan perkawinan di Indonesia, maka ia harus tunduk terhadap semua syarat yang sudah diatur dalam undang-undang yang berlaku.

Hak yang selanjutnya yaitu hak untuk mewaris, dimana anak berhak mewaris harta warisan orang tua apabila memiliki hubungan darah dengan orang tuanya. Untuk melihat hubungan itu harus dibuktikan dahulu status perkawinan orang tuanya, jika perkawinannya sah maka anak berhak mewarisi harta orangtuanya namun jika perkawinan itu tidak sah maka anak hanya memiliki hubungan hukum dengan ibunya dan hanya berhak mewarisi harta ibunya saja. Berbeda halnya dalam kasus perkawinan yang memiliki anak dengan status kewarganegaraan ganda dimana secara otomatis anak tersebut diakui sebagai warga negara Indonesia sekaligus juga sebagai warga negara asing sehingga anak tersebut tidak bisa menjadi ahli waris terhadap harta orang tuanya. Hal itu secara tegas dijelaskan dalam Pasal 21 ayat (1) UU Pokok Agraria yang menyebutkan bahwa "hanya warga negara Indonesia yang dapat mempunyai hak milik". Penjelasan itu dipertegas lagi dalam ayat (3) pasal yang sama dengan menyebutkan bahwa orang asing yang memperoleh hak milik atas tanah pasca berlakunya UUPA wajib melepaskan hak itu dalam jangka waktu satu tahun sejak diperolehnya dan apabila jangka waktu itu lampau dan hak tersebut tidak dilepaskan maka hak itu hapus karena hukum dan tanahnya jatuh pada negara. Ditambah dalam ayat (4) menjelaskan selama seseorang disamping kewarganegaraan Indonesianya mempunyai kewarganegaraan asing makai a tidak dapat mempunyai tanah dengan hak milik atau mewarisi harta orangtuanya yang memiliki harta yang berada di Indonesia.

Solusinya agar anak berkewarganegaraan ganda tersebut dapat mewarisi harta orang tuanya yang berkewarganegaraan Indonesia yaitu hak milik atas tanah, maka pada batas waktu 18 tahun anak tersebut harus memilih untuk menjadi warga negara Indonesia agar dapat memiliki haknya sesuai dengan ketentuan hukum yang berlaku di Indonesia.

Untuk melindungi hak-hak yang sudah dan atau mungkin didapat oleh anak hasil perkawinan campuran, maka diperlukan sebuah upaya perlindungan hukum. Dalam undangundang kewarganegaraan yang baru ini, perlindungan hukum terhadap anak hasil perkawinan campuran dicerminkan dari pemberian status kewarganegaraan ganda terbatas kepada si anak. Upaya tersebut dilakukan agar si anak mendapat kepastian hukum dan mendapatkan perlakuan yang layak karena ia juga memiliki darah keturunan Indonesia dari salah satu orang tuanya. Perlindungan hukum yang sedemikian rupa termasuk dalam perlindungan hukum yang bersifat preventif karena bertujuan untuk mencegah terjadinya pelanggaran-pelanggaran yang mungkin dilakukan dan juga untuk memberi Batasan dalam melaksanakan satu kewajiban bagi si anak (Hadjon, 1987). 


\section{Simpulan}

Dari hasil penelitian yang telah diuraikan, maka dapat ditarik kesimpulan yaitu : 1) Dilihat dari ketentuan Undang-Undang Nomor 12 Tahun 2006 tentang Kewarganegaraan, pengaturan status kewarganegaraan anak hasil perkawinan campuran yang dapat memiliki kewarganegaraan ganda terbatas ini sudah sangat baik, karena dapat memberikan kepastian hukum kepada si anak dan ia juga diakui sebagai warga negara Indonesia setelah mendaftarkan anak-anak hasil perkawinan campuran tersebut untuk mendapatkan affidafit berupa surat keimigrasian. 2) Konsekuensi atau akibat hukum anak yang lahir dari perkawinan campuran yaitu ia menjadi subyek hukum yang hanya mempunyai hak antara lain hak dalam hukum perkawinan dan juga hak dalam bidang hukum waris. Untuk melindungi hak-haknya itu maka diperlukan adanya upaya perlindungan hukum yang bersifat preventif dengan cara pemberian status kewarganegaraan ganda terbatas yang mana anak-anak tersebut akan diakui sebagai warga negara asing sekaligus diakui juga sebagai warga negara Indonesia.

Selaku akademisi Ilmu Hukum didorong untuk memberikan pandangan konkret terhadap fenomena yang terjadi khususnya terhadap pengaturan status kewarganegaraan bagi anak hasil perkawinan campuran serta menganalisis upaya-upaya perlindungan apa saja yang mungkin diberikan oleh pemerintah untuk melindungi hak-hak anak tersebut. Diharapkan pemerintah semakin gencar dan efektif lagi melakukan sosialisasi terhadap substansi dalam undang-undang kewarganegaraan yang baru ini agar kedepannya masyarakat lebih mengetahui bagaimana pegaturan status terhadap anak hasil perkawinan campuran tersebut.

\section{Daftar Pustaka}

Hadjon, P. M. (1987). Perlindungan Hukum Bagi Rakyat di Indonesia (Sebuah Studi tentang Prinsip-Prinsipnya, Penanganannya oleh Pengadilan dalam Lingkungan Peradilan Umum dan Pembentukan Peradilan Administrasi Negara). Surabaya: PT. Bima Ilmu.

Ibrahim, J. (2006). Teori dan Metodologi Penelitian Hukum Normatif. Malang: Bayumedia.

Jehani, L., \& Harpen, A. (2006). Hukum Kewarganegaraan. Bandung: Citra Adyta Bakti.

Sitorus, J. (2004). Perkawinan Campuran Dalam Hukum Indonesia. Jakarta:
Pintu Gerbang.

Thalib, S. (2009). Hukum Kekeluargaan Indonesia (Cetakan kedua). Jakarta: Universitas Indonesia.

Peraturan Menteri Hukum dan Hak Asasi Manusia Republik Indonesia Nomor 22 Tahun 2012 tentang Tata Cara Pendaftaran Anak Berkewarganegaraan Ganda dan Permohonan Fasilitas Keimigrasian.

Undang-Undang Nomor 12 Tahun 2006 tentang Kewarganegaraan Republik Indonesia. 